\title{
DOSSIÊ BERGSON:
}

\section{APRESENTAÇÃO}

Os artigos e ensaios aqui reunidos foram apresentados, em grande parte, no Seminário de Metafísica no Pensamento Contemporâneo, o qual se deu entre os dias 25 e 26/04/2016, no Campus Darcy Ribeiro da Universidade de Brasília.

Tratava-se do primeiro evento da linha de pesquisa em "Ontologias Contemporâneas" do então nascente Programa de PósGraduação em Metafísica (PPG $\mu / \mathrm{UnB})$. O tema deste seminário foi "Bergson - Metafísica e Filosofia da Vida" e contou-se com a participação de professoras e professores de diferentes universidades. $\mathrm{O}$ sucesso deste primeiro encontro suscitou a ideia de torná-lo regular, e um segundo está previsto para 2017, agora na Universidade Federal do Paraná.

O presente dossiê incorpora também trabalhos de professores de instituições estrangeiras com os quais mantemos contatos de pesquisa e ensino. 
Gostaríamos de agradecer ao suporte institucional do PPG $\mu / U n B$, ao financiamento da Fundação de Apoio à Pesquisa do Distrito Federal (FAP-DF) e aos editores da Dissertatio pelo acolhimento dos textos nesta edição.

Evaldo Sampaio da Silva $-\mathrm{UnB}$

(Organizador)

Brasília, Dezembro de 2016. 